\title{
THE CURRENT STATUS OF AND THREATS TO, THE VASCULAR FLORA OF THE FALKLAND ISLANDS, SOUTH ATLANTIC
}

\author{
ESTADO ACTUAL Y AMENAZAS PARA LA FLORA VASCULAR \\ DE LAS ISLAS FALKLAND, ATLÁNTICO SUR
}

Jim McAdam ${ }^{1} \&$ David Broughton ${ }^{1,2}$

The Falkland Islands are an archipelago of 782 islands (Woods 2001) situated in the South Atlantic between latitudes $51^{\circ} \mathrm{S}$ and $53^{\circ} \mathrm{S}$ and longitudes $57^{\circ} \mathrm{W}$ and $62^{\circ} \mathrm{W}$. They cover an area of c. 12,200 $\mathrm{km}^{2}$ and are approximately 500 kilometres from the nearest point on mainland South America. The climate is cool temperate oceanic and is characterised by its lack of extremes. Temperatures are never high but are maintained at a moderate level with a mean for January of $9.4^{\circ} \mathrm{C}$ and a mean for July of $2.2^{\circ} \mathrm{C}$, and ground frosts can occur throughout the year. Rainfall is low with a mean annual precipitation, during the period 1944-1978, at Stanley of 640 $\mathrm{mm}$, though the rainfall received tends to decline towards the south and west. Rainfall is lowest in spring and this, combined with the strong winds, reduces plant growth (McAdam 1985; Summers $\&$ McAdam 1993). Climatic variation across the Falkland Islands archipelago is poorly understood but West Falkland tends to have a milder, drier and sunnier climatic regime, particularly in the northwest.

\section{SOILS AND VEGETATION}

The topography of the Islands is not extreme with the landscape being generally hilly and the tallest mountain, Mt. Usborne on East Falkland, is only $705 \mathrm{~m}$ high. A typical Falkland soil comprises a shallow (usually no deeper than $38 \mathrm{~cm}$ ) peaty horizon overlying a compact, poorly drained, siltyclay subsoil. Mineral soils occur in areas wherever the underlying geology is exposed, particularly on mountain tops and in coastal areas. Falkland soils generally have a $\mathrm{pH}$ in the range 4.1 to 5.0 and are deficient in calcium and phosphate (Cruickshank 2001). The main vegetation types are acid grasslands dominated by Cortaderia pilosa (Poaceae) and dwarf shrub heathland dominated by Empetrum rubrum (Ericaceae), but other vegetation types of more limited extent may be locally important particularly around the coasts. Scrub communities dominated by Chiliotrichum diffusum (Asteraceae) or Hebe elliptica (Plantaginaceae) would have been much

1 Agri-Food and Biosciences Institute \&, Queen's University Belfast, Newforge Lane, Belfast, BT9 5PX. United Kingdom, jim. mcadam@afbini.gov.uk. Fono, 0044 (0) 2890255275. Fax ;0044 (0) 2890255003

2 Falklands Conservation, 41 Ross Road, PO BOX 26, Stanley, Falkland Islands FIQQ 1ZZ. Current contact details: david. broughton@scottwilson.com 
more widespread before the introduction of livestock as was a coastal community dominated by the three metre tall grass, Poa flabellata (Poaceae), which today survives mainly on small offshore islands. There is no native tree cover.

\section{LAND USE}

The history of land use in the Islands is one of little change since post glacial times until man's limited presence from about 240 years ago, when cattle pigs, sheep and goats were first introduced by French settlers (Summers \& McAdam 1993). Sheep were farmed commercially from the 1860 s, numbers increasing up to a maximum of 800,000 in the early 1900s. Stock density declined to about 600,000 by 1930 and remained relatively constant (at a mean stocking density of approximately 1 sheep per 2 ha) until early in the 1980s when a programme of farm-subdivision was introduced (McAdam 1984a; Summers \& McAdam 1993) and since then sheep numbers have increased by approximately 20\% (Summers, Haydock \& Kerr 1993). Some reseeding has been carried out using introduced European forage species but most of the grassland is extensively grazed. Since the late 1990s there have been moves to increase the numbers of cattle on the Islands. The rural population is small (3-400 people) and though most are still engaged in agriculture, farm-based tourism has steadily increased in popularity in recent years and become economically more significant than sheep farming on several inhabited islands.

\section{THE FLORA}

The first botanist known to have visited the Falkland Islands was Antoine-Joseph Pernetty in 1764 (Moore 1968) and botanists have visited the Islands intermittently throughout their history. Over 60 botanists made collections of Falkland Islands plants before 1968, summarised in Moore (1968). Accounts of the flora were produced at disjunct intervals interspersed with long periods of inactivity (eg. Skottsberg 1913; Moore 1968) and it was not until the latter publication that a significant step forward was taken in the understanding of the Falkland Islands flora. Moore's work can be regarded as the first true flora, as with the keys and full species descriptions it contained, it allowed identification of taxa, and as a result was more than just a list of species recorded. In consequence this text is still the definitive guide to the flora of the Falkland Islands and has provided a firm foundation for all subsequent floristic investigation in the archipelago. Recent work (Broughton \& McAdam 2002a,b,c; 2003; Broughton, McAdam \& Brännström 2000) which included substantial field recording, has resulted in significant increase in the number of species recognised, particularly through a substantial increase in the known alien flora (Broughton \& McAdam 2002c) and in our knowledge of the status and distribution of the flora (Broughton \& McAdam 2002a, 2003). Similarly there have been changes to accepted nomenclature, to those species considered endemic, and a gradual increase in knowledge of the flora as a whole.

Seventy-five families, 215 genera, and 363 species have so far been recorded growing wild in the Falkland Islands and are listed in the checklist (Broughton \& McAdam 2005). Of these, fifty-four families, 120 genera and 171 species are native. The substantial non-native flora of 192 species has been (partially) reviewed (Broughton \& McAdam 2002c). There are 18 native and 3 non-native pteridophytes (Broughton \& McAdam 2003).

The Falkland Islands are currently considered to have 13 endemic species. These are:, Chevreulia lycopodiodes, Erigeron incertus, Gamochaeta antarctica, Hamadryas argentea, Leucheria suaveolens, Nassauvia gaudichaudii, Nassauvia serpens, Nastanthus falklandicus, Phlebolobium maclovianum, Plantago moorei, Senecio littoralis and Senecio vaginatus and Calceolaria fothergillii. Two taxa - Nastanthus falklandicus and Plantago moore - are of particular note as they appear to be narrow-endemics, restricted to the southern coast of West Falkland. Calandrinia feltonii was previously regarded as an endemic but recent DNA studies (Hershkovitz 2006) have shown that it is a weedy introduction from western North America, properly classified as $C$. menziesii.

As would be expected the native flora shows strong affinities with that of southern South America. Thirty-three species (19\%) have a 'circumAntarctic' distribution occurring in some part of the sub-Antarctic zone, New Zealand or southeastern Australia, and sixteen species (9\%) have a bipolar distribution, being found also in the higher latitudes 
of North America and to a slightly lesser extent, Europe (Moore 1968). The juxtaposition of the Islands between Antarctica, South America and other remote South Atlantic Islands gives them high biogeographic importance.

\section{Threats to the flora}

a. Reform of rural infrastructure. Land reform in the 1980s has resulted in farm subdivision and increased stock numbers. In many cases this has been accompanied by fencing, pasture improvement and greater stock control but overgrazing and erosion of some of the shallow, fertile soils has occurred. Research activities have greatly contributed to an understanding of the sustainable management of the rangeland vegetation (eg Kerr 2003). Other rural development activities related to oil, fishing, aquaculture and tourism have had limited impact.

b. Plant introductions. The total number of non-native species is now known to be 192 , nearly double that previously recognised by Moore (1968), and exceeding the total for native taxa (171 species) (Broughton \& McAdam 2002c). Taxa come from 46 families of which the Asteraceae (28 species and $16 \%$ of the non-native flora) and the Poaceae (36 species and $21 \%$ of the non-native flora) are undoubtedly the most important. Most non-native species, (131 taxa and 75\% of the non-native flora), show an association with human habitation and other built environments. Of these, approximately 50\% are dependent upon such habitats, reflecting the requirement of many non-natives for open, disturbed or nutrient enriched ground. Other species associated with habitation are more widespread and can also be found in naturally open and disturbed habitats such as beaches and seabird colonies, or in vegetation that has been modified by domestic animals. However, the association of some species with habitation is equally a reflection of their horticultural and agricultural origins and some species, particularly the trees and shrubs, are merely relicts surviving where settlements and gardens have been abandoned. Most non-native taxa were rare or local in occurrence and so probably do not have the competitive ability to spread far in the harsh environment of the Falklands (Broughton \& McAdam 2002c). As man's activities continue to expand and diversify in the Falkland Islands the non-native flora can also be expected to expand and to become more prominent. A similar trend has already been noted in Tierra del Fuego, where the increasing activity of man has undoubtedly extended the area of many non-native taxa (Moore 1983). Cirsium vulgare, for example, arrived in Tierra del Fuego prior to 1917 but was not common. During the 1960s, however, it became more widespread, particularly along roads.

c. Countryside access. Before 1985 there were virtually no roads in the Falkland Islands and building a rural road network commenced. Now a sparse network of roads exists, giving more people from Stanley (the only town) access to the countryside. This, coupled with more leisure time, a greater interest in wildlife, and the growth of the tourism industry has put more pressure on coastal and other sensitive habitats. A road network allows weed species to expand their range. This has already happened with Senecio sylvaticus and Cirsium vulgare may follow the same expansion pattern as on Tierra del Fuego.

d. Fire. As the vegetation emerges from the winter it has accumulated a high proportion of dead matter which creates a fire hazard, particularly in the dry windy spring and summer (McAdam 1984b). The peat soils that dominate much of the landscape are also vulnerable to fire particularly following prolonged periods of dry weather or drought. It is was common land management practice to burn pasture in spring to remove this dead material and to make the greener leaves below more available to sheep, but is used less often nowadays. This practice may have some detrimental effect on the flora but this is not clearly known. Fires can also occur through carelessness and from lightning strikes.

e. Climate change. On a more global scale, climatic change may have a significant effect on the flora of the Falkland Islands (Bokhorst et al. 2007a \& b; Sear at al. 2001; Wadhams 1993). There is evidence that rainfall is slowly declining on the Islands (Hoppé and McAdam 1998) and there are occasional periods when ozone depletion is particularly strong over the Islands. A combination of these processes may well have a significant impact on the flora. 


\section{Current status and distribution}

The extent and distribution of the flora was little known until work by Moore $(1968,1973)$ and, a more thorough and extensive study, a Darwin Initiative (DEFRA) funded project. The latter resulted in the production of a checklist and preliminary atlas of the distribution of the flora (Broughton \& McAdam 2002a); the first comprehensive assessment of the conservation status of the flora and a review of conservation measures in place (Broughton \& McAdam 2002b); detailed studies of floras of specific islands in the Falklands archipelago (McAdam \& Woods 1995; Broughton et al. 2000) and plant groups (Broughton \& McAdam 2003, 2005). These studies have highlighted the general uniformity of the distribution of the flora, though some species, such as Plantago moorei, are extremely rare, localised in distribution and merit further study.

The greatest increases in sheep numbers have been on vegetation types overlying drier; more fertile, soils (such as around ponds), in valleys and on coastal pastures. There is some evidence that soil erosion on shallow soils may have increased in extent because of overgrazing but little is understood of the response of individual communities to increased grazing pressure (Kerr 2003). While sheep grazing has affected the flora considerably there is no evidence to support actual loss of species through the practice. However, two native plant species, Scutellaria nummulariifolia, Saxifraga magellanica and have not been recorded recently and require urgent survey work to assess their current status (Broughton \& McAdam 2002b).

\section{Protection}

Under the Conservation of Wildlife and Nature Ordinance 1999 (FIG 1999) nineteen species of plant are protected. Broughton \& McAdam (2002 b). This, the first Red Data List for the Falklands, contained 23 species and included a further 16 species of relevance to the national conservation strategy. Internationally the conservation of endemic Falkland Islands taxa is perhaps of greatest importance, and should be the focus of priority action. Thirteen species ( $8 \%$ of the native flora) are endemic to the Falkland Islands archipelago. Five of these (43\% of endemics) are threatened (26\% of threatened plants) and one is "Near Threatened". Of the threatened endemic plants, the Antarctic cudweed Gamochaeta antarctica is Endangered, and the other four species are Vulnerable.

The only international Convention currently relevant to the Falkland Islands flora is CITES and the Convention is only applicable to the four Falkland Islands members of the Orchidaeae, only one of which is threatened. All orchids are covered by Appendix II of the Convention. The conservation of wild flora in the Falkland Islands is still in its early stages and has advanced little beyond initiatives to purchase nature reserves. However, with an increase in public awareness and interest in conservation issues, fuelled to some degree by land reform and the increased role of tourism in the economy, there are signs of a shift in focus from protecting sites of high wildlife value to direct action to address conservation problems, such as the development of an ex situ conservation strategy with Royal Botanic Gardens, Kew. In particular, there is a slowly growing awareness of the need to protect and manage threatened plants outside nature reserves and protected sites. This will be vital because most of the species on the Red List are not well represented in the current framework of protected areas. Thus, land-managers whose prime concern is other than with nature conservation may have a significant responsibility in ensuring the continued survival of threatened plant species.

The establishment of a national herbarium, the production of new field guides to the flora (Woods 2000; Liddle 2008) and the production of a conservation orientated visitors guide to the Islands (Summers 2001 and 2005) has encouraged further interest in the flora and its conservation.

\section{Conclusions}

Whilst agriculture and development have been identified as major factors in the decline of some elements of the native flora, it is also possible to implicate a general lack of knowledge of the native Falkland Islands flora and its importance. Given the small size of the Falkland Island's human population, there is scope for halting and reversing the decline of threatened flora. However, this will be dependent on the provision of sufficient resources and increased public awareness. Regular monitoring of threatened plant populations is required along with 
investigations of their biology and the reasons for their decline, and all threatened taxa not currently protected need to be afforded full legal protection. Also, given the importance of conserving genetic diversity (Wigginton 1999; Lesica \& Allendorf 1995), the genetic aspects of rare plant conservation require greater attention.

Most visitors to the Islands (about 60,000 in 2006/07) are cruise-ship based tourists and make little or no impact on the flora. There are a small number of special-interest tourists who visit the Islands, mainly for the wildlife. Such tourists represent a considerable income potential for the Islands and provided their activities are managed in a sustainable manner, as has been recommended for Poa flabellata (Hoppé \& McAdam 1992), such eco-tourism should be viewed as a positive step for sustainable conservation and management of the flora.

\section{ACKNOWLEDGEMENTS}

The work would not have been possible without funding from the UK Government through the Darwin Initiative. The involvement of Falklands Conservation, the Falkland Islands Government and Queen's University Belfast in facilitating the project is gratefully acknowledged. Permission of the Irish Geographical Society to add to a paper they had previously published is acknowledged. The authors are grateful to Robin Woods and Rebecca Upson for helpful comments on the manuscript

\section{LITERATURE CITED}

Bokhorst, S., A. Huiskes, P. Convey \& R. Aerts 2007a. The effect of environmental change on vascular plant and cryptogam communities along a latitudinal gradient from the Falkland Islands to the southern Maritime Antarctic. In: Bokhorst (ed.) Functioning of terrestrial ecosystems of the Maritime Antarctic in a warmer climate. Thesis 2:117-150 Institute of Ecological Sciences, Vrije University Amsterdam

Bokhorst, S., A. Huiskes, P. Convey \& R. Aerts 2007 b. External nutrient inputs into terrestrial ecosystems of the Falkland Islands and the Maritime Antarctic region. Polar Biology 30:1315-1321
Broughton, D.A. 2000. A note on the status of comb-fern in the Falkland Islands. The Falkland Islands Journal 7:1-2

Broughton, D.A. \& J.H. McAdam 2002 a. The vascular flora of the Falkland Islands: an annotated checklist and atlas. Unpublished report to Falklands Conservation. The Queen's University of Belfast, Belfast

Broughton, D.A. \& J.H. McAdam 2002 b. A Red Data List for the Falkland Islands vascular flora. Oryx 36(3):279-287

Broughton, D.A. \& J.H McAdam 2002 c. The non-native vascular flora of the Falkland Islands. Botanical Journal of Scotland 54(2):153-190

Broughton, D.A. \& J.H. McAdam 2003. The current status and distribution of the Falkland Islands pteridophyte flora. Fern Gazette 17(1):21-38

Broughton, D.A. \& J.H. McAdam 2005. A checklist of the native vascular flora of the Falkland Islands (Islas Malvinas). New information on the species present, their ecology, status and distribution. Journal of the Torrey Botanical Society 132 (1):115-148

Broughton, D.A., J.H. McAdam \& R. Brännström 2000. A combined checklist and ecogeographic conspectus for the vascular flora of Saunders Island, Falkland (Malvinas) Islands. Anales Instituto Patagonia, Serie Cs. Nat. (Chile) 28:57-88

Cruickshank, J.G. 2001. Falkland soils - origins and prospects. Unpublished Report to the Department of Agriculture, Stanley. Department of Agriculture for Northern Ireland, Belfast

FIG 1999. Conservation of wildlife and nature ordinance 1999. The Falkland Islands Gazette Supplement 10:2-18

Hershkovitz M.A. 2006. Ribosomal and chloroplast evidence for diversification of western American Portulacacae in the Andean Region. Gayana Botánica 63(1):13-74

Hoppé, G.M. \& J.H. McAdam 1992. Management of a tussac grass community for wildlife, tourism and agriculture. Aspects of Applied Biology 29:413-418

Hoppé, G.M. \& J.H. McAdam 1998. Is the Falklands climate really changing. Wool Press $N^{\circ}$ 109:7-10 
Hoppé, G.M. \& J.H. McAdam 1999. Precipitation in the Falkland Islands 1874 to 1996 . (Abstract) Irish Journal of Agricultural Research 79

Kerr, J.A. 2003. A history of grazing management in the Falkland Islands. Falkland Islands Journal 8(2):94-106

Lesica, P. \& F.W. Allendorf 1995. When are peripheral populations valuable for conservation? Conservation Biology 9:753-760

Liddle, A. 2008. Plants of the Falkland Islands - a Field Guide. 96 pp. Falklands Conservation Stanley Falkland Islands

McAdam, J.H. 1984a. Recent changes in Falkland Islands agriculture. Interciencia 9:307-310

McAdam, J.H. 1984b. The introduction of Holcus lanatus by direct drilling following burning of native grassland in the Falkland Islands. Research and Development in Agricultur 1:165-169

McAdam, J.H. 1985. The effect of climate on plant growth and agriculture in the Falkland Islands. Progress in Biometeorology 2:155-176

McAdam, J.H. \& R. Woods 1995. The flora of Motley Island. The Warra 8:6-7

Moore, D.M. 1968. The vascular flora of the Falkland Islands. British Antarctic Survey Scientific Reports N. 60:1-202. NERC, London

Moore, D.M. 1973. Additions and amendments to the vascular flora of the Falkland Islands. British Antarctic Survey Bulletin 32:85-88
Moore, D.M. 1983. Flora of Tierra del Fuego. Anthony Nelson, Oswestry

Sear C, M. Hulme, N. Adger \& K. Brown 2001. The impacts of global climate change on the UK Overseas Territories. Tyndall Centre for Climate Change Research, Natural Resources Institute. pp. 50

Skottsberg, C. 1913. A botanical survey of the Falkland Islands. Kungliga Svenska Vetenskapsakademiens Handlingar 50:1-129

Summers, D. 2001. A visitor's guide to the Falkland Islands. Falklands Conservation, London

Summers, R.W. \& J.H. McAdam 1993. The Upland Goose. Bluntisham Books, Bluntisham

Summers, O., W.J.R. Haydock \& J.A. Kerr 1993. Land subdivision in the Falkland Islands. Proceedings of the XVII International Grassland Congress, New Zealand 812-814

Wadhams, P. 1993. How the polar regions affect climate change. The Falkland Islands in the 1990s. Proceedings of a seminar. Cambridge: The Falkland Islands Association. pp. 37-40

Wigginton, M.J. 1999. British Red Data Book 1. Vascular plants. JNCC, Peterborough

Woods, R.W. 2000. Flowering plants of the Falkland Islands. Falklands Conservation, London

Woods, R.W. 2001. A survey of the number, size and distribution of islands in the Falklands archipelago. Falkland Islands Journal 7(5):1-25 